\title{
Mapuche Demands during Educational Reform, the Penguin Revolution and the Chilean Winter of Discontent
}

\author{
Andrew Webb* \\ University of Cambridge \\ Sarah Radcliffe** \\ University of Cambridge
}

\begin{abstract}
Enduring inequalities in Chile's education system are both a socio-economic and ethno-national problem. Student protests in 2006 and 2011 are representative of growing public concerns over the neoliberal socio-economic model adopted by respective governments since the military regime ended in 1990. Education has also become a contested space in which the recognition of indigenous rights - and cultural and linguistic diversity in particular - have been negotiated. This article presents an analysis of the history of Mapuche struggles over education, in light of recent neoliberal reforms and political protests. Reforms to address large achievement differentials among indigenous populations have come through proposals for Intercultural Bilingual Education (IBE) in Chile and these, we suggest, have challenged the hegemonic education system and its assimilatory mechanisms. Its current administration, however, reflects minimal commitments to indigenous rights and only the thinnest recognition of cultural difference. Instead, the status quo of mono-cultural and mono-linguistic Chilean nationalism continues to be transmitted via the national curriculum.
\end{abstract}

\section{Introduction}

Public concerns over the inequalities of post-dictatorship Chilean education were first manifested by students in the months of April to August 2006. The Penguin

* Postdoctoral Research Associate on an ESRC project (2011-2014), Ph.D. in Social Sciences at the University of Cambridge in 2010. Research interests include ethnicity and nationalism, globalization, sociology of education, and youth identities.

** Professor in Latin American Geography whose interests include issues of race-ethnicity, popular nationalisms, and social development, particularly with respect to the Andean countries. 
Revolution ${ }^{1}$ saw close to a million secondary students participate in nationwide strikes, school takeovers, and demonstrations. Popular uprising continued in 2011 in what has been labelled the Chilean Winter, with higher education this time the focal point of social discontent, which would surpass the previous protests in political objectives and international media coverage. Both movements represent growing concerns over the neoliberal socio-economic model adopted by respective governments during and since the military regime ended in 1990. The coalition of centre-left Concertación parties, which won four successive elections (19901994; 1994-2000; 2000-2006; 2006-2010), and the current centre-right National Renewal party (Renovación Nacional, 2010 to present) have, according to a number of authors, 'lacked the political will to confront the human rights abuses of the past, to overcome growing economic inequality or to consolidate a vibrant democracy in Chile' (Chovanec and Benitez 2008:43).

That education should have been the vehicle through which such public discontent has been manifest is not altogether surprising. The decentralization of the education system under the military government led to mass privatization of educational establishments, increasing gaps in educational attainment at secondary school level, causing differential access to higher education between socio-economic groups. Despite a number of reforms implemented by the postdictatorship Concertación governments between 1990 and 2003, by 2004 inequity was so prominent that the OECD warned the Chilean government that it would 'have a negative impact on democratic values and institutions' (Matear 2007a:61). This effectively was the case as growing tensions finally gave rise to the civil protests in 2006.

Enduring inequalities in the Chilean education system are not merely a socioeconomic problem but also an ethno-national one. Indigenous populations suffer marked educational differentials from non-indigenous dominant groups, who claim descent from European settlers in the same districts, and are among those most likely to repeat academic years, enter school late, and have among the lowest retention figures (McEwan 2004). Since the return to democracy, efforts have been made to address this achievement gap via reform programmes such as P-900 and MECE Rural, which targeted low achievement and isolated rural schools respectively (see below). However, these reforms acknowledged nothing of the cultural or linguistic needs of indigenous peoples themselves. By failing to acknowledge the multicultural makeup of its citizens, education has therefore become a contested space in which recognition of indigenous rights - and cultural and linguistic diversity in particular - have been negotiated.

Small advances have been made since the return to democracy in regards to ethnic minority-state relations, such as the ratification of the International Labor Organization 169 Convention, and the national Indigenous Law of 1993. Yet there remain certain fundamental principals in Chilean politics which impede the meaningful acknowledgement of the rights of cultural Others, most notably in the constitution. ${ }^{2}$ Education is no exception to this, and it was not until 2000 that Intercultural Bilingual Education (IBE) was introduced by the Ministry of Education $(\mathrm{MoE})$ on a limited basis into selected schools. Serious questions hence remain over the extent to which such reforms represent an opening of dialogue 
between indigenous peoples and the state, and the extent to which Chilean IBE exemplifies neoliberal multiculturalism, namely a form of management of ethnic difference subject to the forms of governmentality and constricted cultural expression. Education, under this governmentality, acts as a pivotal intermediary for constructing a citizenry that responds to contemporary state practices and its social organization. According to Mitchell (2003:388), national education programmes are increasingly moving towards the development of 'globally oriented state subjects' capable of excelling in internationally competitive markets. The promotion of equal access to quality education, whilst acknowledging national diversity, therefore often emphasizes the uniformity of individuals to state goals, norms, and rules.

In the case of Chile, whilst the multicultural makeup of the state is recognized in educational policy, schooling practices remain influential in recreating monocultural citizen-subjects capable of responding to the economic and social requirements of the nation-state under its neoliberal model. Neoliberal multiculturalism is therefore intricately associated with recent reforms of education, health, political rights, and development across various Latin American countries (Hale 2002). Indigenous and popular protests against the restrictions on political rights and cultural expression associated with neoliberal multiculturalism have also been documented (Postero 2007; Sieder 2002).

As part of an ongoing project that explores multiculturalism in Chilean classrooms, and the design, implementation, and effectiveness of IBE in particular, this article examines Mapuche ${ }^{3}$ demands for more equitable and inclusive education within the national space from 1910 up to the present. We draw on a variety of academic sources (primarily published in Spanish in Chile), public policy documents, and first-hand interview data to demonstrate how ethnic-state relations have been negotiated via spaces of education. The article presents an analysis of the history of Mapuche struggles over education, in light of recent neoliberal reforms and political protests. Chile has historically taken a notably exclusionary stance towards indigenous populations, and in recent years has switched to a discourse that recognizes diversity but fails to introduce systematic reform (Richards 2010). Indeed, Chile stands out in the Latin American context for its early adoption of neoliberalism, and its late and reluctant multicultural reforms. Proposals for Intercultural Bilingual Education (IBE) in Chile, we suggest, have challenged the hegemonic education system and its assimilatory mechanisms, but its current administration reflects minimal commitments to indigenous rights and only the thinnest recognition of cultural difference. The status quo of mono-cultural and mono-linguistic Chilean nationalism will likely continue to be transmitted via the national curriculum.

We begin with a review of educational reform in Chile, followed by the long-standing concerns of the Mapuche people regarding the state's ideological use of the education system. In continuation, we examine the resultant IBE model as a potential means of altering the asymmetrical relationships contained therein. Finally, we demonstrate how multicultural concerns interconnect with the policies that led to the social and political mobilizations of 2006 and 2011. The unfolding of each of these events, we suggest, represents more widespread concerns over the 
country's neoliberal economic model and limited socio-political rights offered to its citizens, which are intricately linked to Mapuche demands for intercultural practices within national spaces.

\section{Reform and Inequalities in Chile's Education System}

In 1981, under the military dictatorship, Chile adopted a national school voucher system 'as a way to improve education under severe cost constraints and to decrease central bureaucracy by shifting financial and educational decision making to local governments and private households' (Carnoy 1998:309-10). Pinochet's neoliberal free-market model for the country justified these reforms as promoting competition between schools so as to improve their efficiency and educational standards (Matear 2007b). National teacher unions were abolished and teacher contracts were privatized. The private sector therefore entered the market as a provider of education and the vouchers, paid directly to each school according to school attendance, were used to pay for general running costs (Anand et al. 2009). In effect, a quasi-market between education providers was created in which schools effectively used 'merchandising' tools to sell to the general public (such as with the use of prestigious English names) (Espinola 1993). Even more importantly, a socio-economic divide was created because of differential access to the private subsidized schools that introduced selection procedures in order to screen out children perceived to be less academically able.

The voucher system therefore did nothing to improve student achievement levels in terms of national school quality; rather, it only led to a growing gap between private-subsidized schools which benefitted, and municipal schools which were hindered (Carnoy 1998; Delannoy 2000). Moreover, the day before Pinochet surrendered power in 1990, his government introduced the Constitutional Organic Law of Education (Ley Orgánica Constitucional de Enseñanza - LOCE). This law established the normative requirements for any institution wishing to be formally recognized as an educational establishment, thus paving the way for further expansion to the private market of school provision in Chile. As a result, state-subsidized private primary schools in rural areas of southern Chile boomed during this period, but received little regulation over the demand for education in the geographical proximity to the schools, the quality of education provision, or the motives behind their creation (Espinola 1993).

With the return to democracy, President Aylwin's (Concertación) government was impeded from making substantial policy and implementation changes to the education system, due to the predominance of senate politicians from the previous government. In this context, changes to the LOCE as a constitutional matter were unattainable, and later governments of the Concertación would also settle for a 'politics of pragmatism', focused on increasing public investment in education (Matear 2007a:65, 2007b). Aylwin's government consequently initiated a number of programmes to improve the quality of the national education system. In particular, the P-900 programme was introduced in 1990 in an attempt to target vulnerable schools (assessed by their average test scores from 1988) in rural areas wherein $90 \%$ of available resources were destined towards infrastructural changes 
and resources for these high risk schools (Matear 2007b; McEwan 2008). The MECE programme (Programa de Mejoramiento de la Calidad y Equidad de la Educación, Programme for the Improvement in Quality and Equity of Education), co-funded by the World Bank and Chilean government, began in 1991 in an effort to reform primary education, particularly in regards to classroom effectiveness, new curriculum modules, and better teaching resources (Matear 2007b). These initiatives, however, despite being implemented in areas of high percentages of indigenous populations, did little to alter hegemonic forms of education. By failing to accommodate the needs of pupils from different ethnic groups, Chilean education curricula remained mono-cultural and mono-linguistic. The Indigenous Law, in effect from 1993 and containing direct references to the government's responsibilities towards developing an intercultural and bilingual education in Chile, was not acted on. This reform illustrates Chilean nationalism's fraught relationships with ethno-racial difference.

Eduardo Frei Ruiz-Tagle's term as president (1994-2000) saw more extensive educational reform take place (under the banner of the National Commission on the Modernization of Education). The MECE programme continued, moving on to the secondary level. Among the other reforms, arguably the most decisive was the implementation of the Full School Day (Jornada Escolar Completa - JEC) in 1997, which sought to improve the quality and equality of children's education across the country. Weekly hours of schooling were raised from thirty to thirtyeight in primary schools, and from thirty-six to forty-two in secondary schools in accordance with other OECD countries. Problems, however, remained with poor infrastructure in many schools and the limited allocation of resources for such reform. Additionally, the abruptness with which the policy was implemented led to concerns over the education budget, the organization of the national curriculum, a lack of clearly communicated objectives from the ministry, and the impact it would have on teachers and pupils alike (Delannoy 2000). In short, the reform was not well received by the Chilean public or the teachers' union.

Nevertheless, under Frei's term of office, the first steps were taken to design an IBE programme. Initially a pilot scheme was established across seven regions of the country, with each pilot scheme supported by a university in that region (Ministry of Education 2011). From 1994 to 1996, both CONADI (Corporación Nacional de Desarrollo Indigena) and the Ministry of Education (Mineduc) worked together with a core group of individuals in order to coordinate these efforts to initiate IBE. Following this (1996-1999/2000) CONADI also supported eight schools with previous experience in developing innovative curricula related to bilingualism and interculturalism (two nurseries, one secondary school, and five primary schools) with a view to expanding and deepening this experience (Cañulef 1998). These would mark the first steps towards multicultural education in Chile. These initiatives, however, remained deeply embedded in neoliberal premises and forms of governance, characterized by isolated, limited reforms and budgetary limitations in other schools. That is, the piloting of these projects failed to provide a platform from which to effectively expand IBE in Chile. According to two government officials who participated between 1996 and 1999 in Lumaco, implementation lasted only for as long as the projects were funded, and the schools soon 
reverted to the traditional education system once this ceased, whilst the pilot experience itself was 'not taken as a reference' for future IBE implementation since the reports were not adequately disseminated or analysed. ${ }^{4}$

The third consecutive Concertación government (2000-2006) saw Ricardo Lagos, the education minister under Aylwin, elected as president. In this context, it was unsurprising for Lagos to further reform the Chilean education system; by raising the minimum number of years for compulsory education from eight to twelve, whilst also completing the cycle of the MECE programme at university level (Matear 2007b). More surprising, however, were the events that would transpire a year into his presidency with the first student mobilizations organized in Santiago, as described below. Education reform was also due to follow along a similar path following Michelle Bachelet's election as president (2006-2010), whose election manifesto contained a commitment to expanding pre-schooling and the JEC (Burton 2012). Despite these proposals, Chile's education policies would be rocked by its student population just three months into Bachelet's term of office, recording the largest student mobilizations in Chile's history in response to enduring inequalities.

In this section we have summarized the main reforms implemented by successive Concertación governments following the return to democracy in 1990. As part of the country's neoliberal model, education was given a prominent place in Chilean politics since it was acknowledged to be a key determinant of national development (Matear 2007b). During these years government spending on education steadily increased and policies were directed towards improving the quality of education provision and pupil retention. However, more significantly, the governments failed to address the serious inequalities of access caused by the LOCE. These inequalities particularly affected low-income groups including indigenous groups and large numbers of Mapuche. Additionally, these reforms would fail to challenge the homogenous national education offered to all its citizens despite the rights to IBE validated under the legislation of the Indigenous Law of 1993.

In the next section we outline the ways in which Mapuche movements have disputed the assimilatory tendencies of the Chilean education system since national independence. After decades of political intervention, the Mapuche challenge would eventually lead to the establishment of a certain type of IBE. In the remainder of the article, we detail the ideological significance of the IBE programme as a means of contesting Chilean nationalism and state-ethnic relations.

\section{Mapuche Demands for Education (1911-1990)}

Mapuche demands for reform to Chile's education system long predate the uprisings of the last decade. The Chilean educational system has, since independence, been primarily concerned with the assimilation of Mapuche and other indigenous peoples into a singular 'Chilean' national identity. Following their confinement and marginalization to reservations (reducciones) in 1883, public perception of the Mapuche was that they had gone from being Indians to rural peasants (campesinos). Education would play an important role in reinforcing this perception by attempting to create mono-lingual and mono-cultural citizens. Part 
of the state's strategy was to eliminate any possible revolts by re-socializing the children of the most influential Mapuche leaders. To this end many of the Caciques' children were sent to the towns of Concepción and Chillán to be educated in Catholic missionary schools. However, not all Mapuche who attended these schools were assimilated in a depoliticized way. ${ }^{5}$ As Serrano (1995:459) notes, 'the mission education demonstrably did not entail a process of acculturation for the Mapuche but rather the acquisition of functional instruments for their own ends'. A number of Mapuche who learnt to speak, read, and write Spanish found these assets to be empowering and prestigious both within their communities and as a means of forming political alliances across Chilean society with a view to defending indigenous rights. Most notable among the Mapuche intellectuals and politicians of the early twentieth century were Manuel Manquilef, Manuel Neculman, Manuel Aburto Panguilef, and Venanacio Conuepan, each of whom formed organizations with a view to protecting their cultures and rights to land (Bello 1999; Bengoa 1985; Crow 2010).

The earliest of these, Sociedad Caupolican Defensora de la Araucanía, in 1911, led by Manuel Manquilef, took an 'integrationist' stance towards Mapuche-state relations. Whilst advocating the need for the protection of cultural customs and the 'defence of the race', they also encouraged insertion into civil society via the privatization of Mapuche lands and participation in state education in order to help the Mapuche progress. Such was the preoccupation regarding education for Mapuche children that would be instrumental in the founding of the first primary school in Temuco (Bengoa 1985). The Federación Araucana led by Manuel Aburto Panguilef, in contrast, proposed the formation of an Indigenous Republic, emphasizing cultural autonomy as a means of defending the identity of the Mapuche (Crow 2010). Both these, and other indigenous organizations of the time, challenged the national hegemony regarding a homogenous citizenry, bringing the unique cultural, linguistic, and 'racial' differences of the Mapuche to the centre of Chilean politics.

An important date marking the first official petition of autonomy over the education of Mapuche children occurred on 11-14 December 1935, when the Junta General de Caciques del Butahuillimapu gathered Mapuche and Huilliche ${ }^{6}$ leaders in Curaco, Osorno, in order to assemble a Memorial and Documentation for the President of the Republic, Arturo Alessandri. This document established two important principles regarding Mapuche relations to Chilean educational provision, namely the replacement of German missionary priests with Mapuche (or mestizo Chileans) who were to teach in the missions, and secondly the creation of autonomous schools within each reservation where Mapuche teachers and Mapuzungun-language teaching materials could be used to instruct the children (Cañulef 1998).

In the same year, Zenobia Quintremil ${ }^{7}$ made a formal presentation to a society of indigenous teachers (Concentración de Profesores de Escuelas de Carácter Indigena) to adapt educational format and content according to the specific socio-cultural reality of each reservation (reducción). Her speech framed education not merely as a means of transmitting cultural knowledge, but as a 'weapon' against the 'new conquest' of the state (Foerster and Montecino 1988:260). In 
1939, during the first Radical Party government in Chile, the Conference of Radical Teachers (Congreso de Profesores Radicales), presided over by Jose Inalaf, named a new commission for indigenous schooling. Among its objectives were: (1) the immediate creation of polytechnic state schools that consider the local concerns of agriculture, horticulture, farming, etc. in the Araucanía Region; (2) Spanish and Mapudungun (Mapuche language) to be taught during the first years of primary school; (3) incentives for increasing the number of Mapuche teachers, via a one-year teacher training scheme; (4) obligatory service within reservation schools for three years for recently qualified Mapuche teachers with additional remuneration provided by the government as an incentive; (5) the designation of a secretary of indigenous education; (6) the establishment of an indigenous teacher training institute with increased funding; and (7) the creation of opportunities for Mapuche professionals and teachers to gain further education training overseas (Foerster and Montecino 1988:263).

The 1940s further evidenced growing Mapuche concerns over the education system for indigenous children. In 1946, the First Pedagogical Conference of Mapuche Teachers took place, during which the possibility of a complementary school system for Mapuche pupils was discussed. This was 'the first time the educational problem of the Mapuche people was dealt with in a specific and independent manner from the rest of [Mapuche] organizational demands' (Foerster and Montecino 1988:267). From this period onwards, demands for education would shift towards a focus on obtaining better education standards for the new generation of Mapuche youth. In particular, the growth in migration to urban areas during the 1940s and 50s provoked increased interest in obtaining greater access to higher education. Although education had been intended as a vehicle for assimilating the Mapuche into national citizenry, a new generation of indigenous students began to organize themselves with a view to using the state-education as a means of furthering their own interests. This led to a new generation of Mapuche leaders who obtained university education and were able to frame their demands for indigenous rights in terms increasingly formalized in international conventions and standards (Bello 1999).

These concerns have seldom been addressed by the Chilean state up to the present day. Private initiatives have gone some way in compensating for this, such as the Catholic Church which in 1991 addressed the omission of qualified teachers by creating a university course for intercultural primary school teacher training. ${ }^{8}$ The Concertación governments went as far as recognizing both an ongoing debt to indigenous peoples residing in Chile and the inaccurate and inadequate accounts of historical events pertaining to those peoples via an official document published in 2003. ${ }^{9}$ A public policy document of 2008 lists, as one of its plans of action, the modification of educational curricula to correct this deficit, ${ }^{10}$ yet like much of state-Mapuche relations over recent decades, this rhetoric has not been converted into practice.

Mapuche demands for education continued to be presented to the respective liberal and socialist governments during the 1960s and 1970s along similar lines. During the former, Eduardo Frei's government (1964-1970), educational reform brought about a new emphasis on the methods and techniques of teaching, with 
greater flexibility offered in the curriculum for meeting the needs of the pupils in each region of Chile according to their socio-cultural context (Cañulef 1998). Most Mapuche demands remained focused on greater access to education, including boarding facilities in both urban and rural schools, and school food vouchers for poorer pupils (Bello 1997).

During the 1970s, under the presidency of Salvador Allende (1970-1973), some of the Mapuche demands were met - principally as a result of the government's politics, which was open towards indigenous peoples and the recognition of national diversity. During his candidacy, Allende signed a document which attempted to reconfigure state-Mapuche relations. This Compromiso Histórico (the Historic Commitment) was signed by the president and representative Mapuche leaders, and established, among other important elements, to provide 'a primary education which foregrounds the maintenance of our [Mapuche] language and which directs teacher training towards a professional and locally-informed method and which opens up possibilities for higher university education' (Marimán 1995:13). Although the implementation of this policy was cut short by the coup d'etat, Allende's government did create an Indigenous Law (17.729) which promoted funding for Mapuche students, technical and vocational education, and the establishment of hogares for Mapuche students in order to facilitate access to higher education. In the wake of the growing urbanization of Mapuche populations, the Federation of Mapuche Students of Santiago (Federación de Estudiantes Mapuche de Santiago) was formed in 1970. In the following years, the Federation of Secondary Students worked towards the application of the Indigenous Law (personal testimony of an indigenous leader given in Bello 1999:21).

Through the Institute of Indigenous Development (Instituto de Desarrollo Indigena, which was part of the Department of Indigenous Affairs or Departamento de Asuntos Indigenas), funding, known as the Beca Indigena, was also greatly increased for Mapuche students. ${ }^{11}$ Mapuche intellectuals continued to press for more radical reform to the education system. Although advances had been made in regards to access to higher education, the quality of primary schooling in rural areas was poor and its content remained mono-cultural. These demands led to the implementation of the Rural Mapuche Education Programme (Programa de Educación Rural Mapuche), which ran from 1978/79 to 1995, and was later continued under the broader IBE programme. Some of the initiatives included sensitizing teachers to socio-linguistic and cultural differences among Mapuche pupils, and workshops such as traditional weaving and carpentry as technical forms of education for those pupils who would not obtain many years of education.

The period of Pinochet's government marked a parenthesis around indigenous demands for education. During this time, many of the initiatives that had achieved significant reform were either discontinued or reduced, as was the case with indigenous grants which steadily decreased during the 1980s (Bello 1997). The socialist government, which had been open to the recognition and inclusion of ethnic diversity, was replaced by a 'politics of omission', as the dictatorship sought to instigate a neoliberal economic and social model of national growth and stability for a homogenous Chilean society (Serrano 1995:473). According to 
Sznajder (2003:25), 'provisions favouring Mapuche education, professional training, technical education, the establishment of centres or crafts, and the application of preferential quotas for Mapuche students applying for higher education, characteristic of previous Chilean legislation, and especially of law 17.729, the Ley Indigena, were absent from decree 2.568 ' enacted by the military government in 1979. In short, the existence of the Mapuche during this period was negated in favour of a universal Chilean peasantry (Carter 2010). However, during this period a number of non-governmental organizations (NGOs), international development agencies, and religious institutions, most notably the Catholic Church and the German Agency for Technical Cooperation (GTZ), who recognized the value of education for improving state-ethnic relations, worked together with indigenous intellectuals towards the creation of IBE (Ortiz 2007).

\section{Intercultural Bilingual Education: Reworking Ethnicity, Nationalism, and the State}

The objectives of the IBE model were to establish indigenous rights to autonomy in the design and implementation of an educational system that would acknowledge and validate their own knowledge systems. This in turn would be premised on the creation of a new type of Chilean-Mapuche relations; based on equal citizenship rights within a framework of difference. The basis of interculturalism was to address racism in order to create inter-ethnic relations founded on equality of dialogue and learning between cultures. These goals went hand-in-hand with the transition to democracy, and together with presidential candidate Aylwin, the Mapuche worked on proposals to reform the Indigenous Law (19.253) so as to recognize, respect, and promote indigenous rights to lands, culture, and education. Despite the acceptance of IBE demands within the reformed Indigenous Law, not all the terms requested by indigenous groups were accepted by the National Congress (Cañulef 1998:141). This would be a recurring issue for ensuing ethnicstate debates over interculturalism within education over the following two decades.

As a political and ideological positioning, IBE in Latin America has, at the very least, introduced 'a new politics of knowledge to the centre of struggles over the state itself' (Gustafson 2009:2) and has initiated a process of 'educational decolonisation' (Howard 2009). However, as a pedagogical practice, it has in many cases failed to transition those ideals into the classroom (García 2005), and, in the majority of cases, remains a compensatory model (rather than one of true dialogue) which the state offers as a controlled space for indigenous 'inclusion' (or exclusion) reserved only for appeasing the recognition of cultural diversity (Chiodi 2005). Montecinos (2004:37) suggests that IBE in Chile is, 'an invitation for one sector of our society to become bicultural' since it is not an obligatory subject for non-indigenous Chileans, and therefore 'runs the risk of maintaining indigenous peoples in a status of Other (read culturally dominated groups)'. Rather than representing emancipation, some indigenous actors involved in this process believe IBE to be the subjugation of the indigenous subject under the guise of multiculturalism. ${ }^{12}$ Whether this is indeed the case, the existence of IBE and 
interculturalism as an indigenous demand brings state-Mapuche relations, and the inappropriateness of the education apparatus used to build a homogenous nation with a unified culture, under scrutiny.

\section{Advances in IBE}

In 2000 the Ministry of Education created the Intercultural Bilingual Education Programme (Programa Educación Intercultural Bilingue - PEIB), which began to construct a policy of expansion and slowly to implement IBE in areas of high concentrations of indigenous populations. Until 2001 these pilot schemes remained isolated and not very numerous. However, in 2001 the Origins Programme (Programa Orígines) was established, following a US\$133 million proposal by the Chilean government, which included a US\$79 million loan from the Inter-American Development Bank (IDB). The programme's broader development objectives for forty-four comunas and 645 indigenous communities also included a component on intercultural bilingual education. The IBE element of the Origins Programme was primarily organized around the distribution of grants/ funding for indigenous school pupils and university students. After consultation with Mapuche organizations and representatives, the programme applied the IBE model in 162 rural schools at a cost of over $\$ 3,000,000,000$ Chilean pesos (approx. US\$6 million), spent on activities that included teacher training, the creation of intercultural texts, and assistance in the creation of Educational Plans for each school, so as to generate IBE curricular content.

Upon completion of Programa Orígines in 2010, the Ministry of Education continued to fund the development of IBE in each of the schools that had been initiated under Origines. Education Decree 280 was introduced in the same year with a view to establishing the norms under which indigenous languages would be incorporated into the official curriculum to pupils in schools with over $50 \%$ indigenous enrolment; and as of 2013, including those schools with indigenous enrolments of $20 \%$ to $49 \%$. The decree establishes the year in which this will take effect, progressively moving from first year primary schooling in 2010, up to the eighth year of primary schooling by 2017 (Ministry of Education 2009). This, to date, remains a voluntary process, thereby making it possible for Mapuche and non-Mapuche pupils alike to withdraw from this intercultural content. IBE therefore remains constrained by the neoliberal multicultural paradigm in Chile to the extent that it remains a system that is thought of as being for indigenous pupils, despite being those who are already adept at moving between both cultures and languages. IBE is rarely presented as a system that is necessary for non-indigenous Chileans in order to bridge the gap within the nation so as to include all its citizens on an equal footing.

Beyond the (limited) advancements in IBE, interculturalism (interculturalidad) remains a critical rhetoric in the hands of indigenous movements, which challenges the political status quo of exclusion, or, recently, a recognition of folkloric diversity that maintains the balance of power in favour of the nation-state whilst appeasing certain lesser demands ${ }^{13}$ (Park and Richards 2007). For this reason, Mapuche students have recently reiterated their demand for more progressive 
reform to higher education in Chile, which includes the possibility of a Mapuche university. Indigenous universities have emerged over recent years in a number of Latin American countries as part of indigenous movement efforts to continue the professionalization and consolidation of indigenous knowledges.

\section{The Practice of IBE in Chile}

According to many actors currently involved in the design and implementation of IBE in Chile, the government's initiatives (PEIB) have been insufficient due to a lack of financial resources, continuity of implementation, IBE specialists, and above all, the lack of state and public 'recognition of the educative and linguistic rights of indigenous peoples' (Loncón 2010:84). One of the few independent reports written on the status of Chilean IBE in recent years concludes that IBE is conceptualized in such limited terms that it is 'reduced to the incorporation of only a few improvised [artisanal] practices, in schools. Additionally IBE is often understood [by educators] as specific and defined content, such as a course or teaching resource, rather than as a perspective or focus' (Organización de Estados Iberoamericanos 2009:135).

Interviews conducted with personnel from the PEIB in the Mapuche-majority region of Temuco during 2011-2012 reveal similar concerns over the development of IBE. One employee, with over fifteen years experience in IBE suggested that at present the education system only considers Mapuche knowledge and methodologies to be relevant to specifically designed isolated units within the curriculum:

We are still far from being able to say that we have an intercultural education curriculum. We are far off because the way paved out for children in the schools is that a mathematics teacher comes in and the Mapuche child no longer exists, ethno-mathematics does not exist. Counting or adding in Mapudungun doesn't exist. The child goes into social sciences, say a history [class]; in some unit they will speak about the issue of pre-Columbus peoples and whatever, but in the next they will pass on to teaching materials about the history of Chile, 'the official' history, and that section which [teachers] transmit regarding this other history says 'you are Chilean, you are a citizen of this country'. But it doesn't take into account the fact that one is Mapuche. It is not a curriculum which says 'you can know about this, but you are this', so [IBE] is like a small capsule where suddenly the Mapudungun language is incorporated like English or French.

(Interview, January 2012)

The incorporation of indigenous languages into the curriculum, according to the same employee, is therefore a double-edged sword. On the one hand, progress is being made to address the glaring omission of Mapuche language and culture from Chilean classrooms, whilst on the other, interculturalism as a means of emancipation, recognition, and mutual understanding is notably absent. Instead, IBE represents a token form of compensation that separates Mapuche culture and educational content as Other within educational spaces. The PEIB recognizes diversity, but only as a folkloric compliment to the rest of the curriculum - 
sporadic extracurricular events, such as the enactment of traditional Mapuche rituals, but without substantive content. The IBE sections of the curriculum are fragmented and isolated, and understood by teachers as extracurricular, or additional, to the core curriculum. By contrast, the 'official' core curriculum is perceived as holistic, coherent, and continuous. A Mapuche teacher argued that this fragmentation of Mapuche knowledge in relation to a still-dominant 'national' curriculum affects in turn the transmission of indigenous knowledge:

The [Mapuche] knowledge has to be so forced in order to fit it in here [the core curriculum], so Mapuche knowledge and the language taught in schools are brought in from perspective of the Western world, or from the pedagogical perspective, [dominant social norms of pedagogy], from a 'schooling' with a western logic. So I sort of see this [IBE] as being an integrationist thing.

(Interview, December 2011)

School spaces therefore continue to be founded within hegemonic nationalist mindsets with the attendant racial hierarchies, and exclusions, of Other knowledges. Both the content and the lived-experience of education are divided sharply in practice and discourse between what is normal and authentic and what is Other. Under the terms of this nationalism, the racialized Other is permissible only as long as it adheres to characteristics of dominant ethno-national identity, or is positioned in subordinate relation to Chilean ethnonationalism.

In addition to defining which spaces IBE can exist within, the state also controls how it is implemented. It does so via bureaucratization, what in Foucauldian terms would be the governmentality associated with the 'conduct of conduct'. Each establishment wishing to implement IBE must establish a unique plan and programme (Planes y Programas Propios) and coordinate it with the Institutional Educational Plan (Plan Educativo Institucional). Each academic year the school must also develop an Annual Plan of Action (Plan Anual de Acción) that corresponds to this programme (Ministry of Education 2011). This clearly represents a large amount of administrative work, which culminates in completing the Formulario de Presentación de Proyectos, Fondo de Adecuación de Instrumentos de Gestión Curriculares y Propuestas Innovadoras - all of which must be approved by the local education authority. With the limited funding provided by the Ministry of Education, only privately subsidized schools are in a position to make more systematic changes in order to incorporate IBE content across the curriculum, meaning education opportunities are again governed by the neoliberal policies within the country which favour privatized education provision. Most of these establishments, however, do not consider IBE to be relevant to the creation of globally competitive citizens. The creation of intercultural schools, particularly at the secondary level, has therefore been limited to a few third sector organizations in Chile such as the Guacolda school, funded by the Fundación Instituto Indigena, in Chol Chol.

Since education is decentralized in Chile, the main onus of these bureaucratic demands falls on head teachers in the schools. Incorporating IBE therefore means departing from the routine administrative duties of each school and also requires a 
certain level of training and competence in order to comply with these criteria. IBE tends to be introduced in school districts where over $50 \%$ of school enrolment comprises Mapuche children, under the current policies of Education Decree 280. Outside of these districts, there is no requirement for IBE to be incorporated into the school curriculum, except in cases where schools design the education programme (providing they fall within the minimum and obligatory content set by the Ministry of Education) and apply for IBE to be implemented. To date, the Catholic Church remains one of the few organisms to do this, although in recent years limited instances of indigenous communities assuming responsibility for the administration of primary schools have arisen. ${ }^{14}$

Despite obstacles to the implementation of IBE in Chile, the ideological significance of Mapuche demands for recognition of the cultural, social, and political legitimacy of the indigenous Other have been more far-reaching. That is, they occupy a similar political space as the educational demands made by student populations in recent years which have scrutinised the equality of Chile's social structure and the efficacy of its neoliberal reforms for its citizens. Demands made for increasing quality, an end to profiteering in tertiary education, and more equitable admission processes sought to put an end to exclusionary practices by the state in regards to the socio-economically skewed distribution of students within the country. Within these social movements, a number of indigenous actors have been interlocutors in drawing attention to the state's hegemonic citizen buildingproject and schooling as a mechanism for this social reproduction. Below we address each of these social movements in turn before demonstrating how ethnic demands contributed to, broadened, and even re-shaped, the structure and impact of these movements.

\section{Contemporary Politics of Education and Nationalism: Student Protests}

Although student protests had been organized under the Allende and Pinochet governments, following the return to democracy Chilean students became disassociated with political activism and labelled as disinterested (Chovanec and Benitez 2008; Wolf 2009). However, two changes to education-related matters contributed directly to the first student mobilizations in 2001: price rises on public school transport passes (Pase Escolar) and the introduction of examination fees for university selection (Prueba de Selección Universitaria, PSU). The protests of 2001 were relatively minor in scale (in the low thousands) and limited to the capital city, Santiago. However, the government were forced to respond by allowing a group of secondary students - Agrupación de Centros de Alumnos Municipales de Santiago (ACAS) - to be included in weekly meetings with the Education Minister, Sergio Bitar, over educational reform in 2005 (Wolf 2009).

\section{The Penguin Revolution}

President Bachelet's term in office (2006-2010) was marked by a series of protests and strikes by secondary school students on a national scale. Demands remained focused on socio-economic inequalities including earlier concerns over the uni- 
versity entrance exam fees and public transport costs (which they demanded be free), and grievances over the JEC. But as the movement gathered force, it increasingly addressed the need for structural changes to the constitutional education law (LOCE) and access to higher education for pupils from lower socioeconomic groups.

The protests began in Lota in the Bio Bio Region on 25 April 2006 when more than 2,000 secondary school students marched to raise awareness about poor school infrastructure (Wolf 2009). The following month saw a number of independently organized school take-overs as well as minor demonstrations organized by the newly formed Asamblea Coordinadora de Estudiantes Secundarios (ACES, Coordinated Group of Secondary Students) in response to Minister of Education Martin Zilic's failure to meet with the student movement or respond to their demands (ibid.). The central government was notably negligent in taking these demonstrations seriously, exemplified when President Bachelet refused to address educational reform or the student movements directly in her presidential speech on 21 May (Chovanec and Benitez 2008). Further antagonism was stirred by the national police force's heavy handling of these initial demonstrations. From this moment the student movement quickly escalated in scale, resulting in a national strike on 30 May, bringing between 600,000 and one million pupils onto the streets to demonstrate.

This provoked an immediate response from the president who gave a television address about her proposed reforms, which would alter the LOCE and JEC. The reform also included increased participation in decision-making for students via a Presidential Advisory Council on Education (Consejo Asesor Presidencial de Educación - CAP) on which they were granted six seats ${ }^{15}$ (Wolf 2009). On the 9 June, ACES announced the official end to the mobilizations having accepted the president's terms. Although further demonstrations were held, the student mobilizations lost momentum after this point, and work began on replacing the LOCE with a new General Law of Education (Ley General de Educación).

The Penguin Revolution marked an historic moment - a new generation had challenged the legitimacy of the education system left by the dictatorship and, perhaps even more significantly, scrutinized the political agenda of democratic governments. The neoliberal model, which had brought economic growth and stability, was publically denounced as creating inequality within the nation. The civic action of the pupils' civil protests therefore shone a harsh light on Chilean politics of education, bringing into question individual and collective rights in a polarised society with deep underlying social contradictions.

\section{The Chilean Winter of Discontent}

2011 was an even more tumultuous year for Chilean politics, as students took to the streets across the country to protest glaring inequality in access to university places and the quality of university education provision. However, the student-led movement would this time challenge the political status quo of the country and became a populist uprising of greater dimensions than the 2006 protests. Labelled in the 
media as a Chilean Winter (of discontent), ${ }^{16}$ the protests were symptomatic of the general public's growing concerns and disquiet regarding the country's political economic model. ${ }^{17}$ Decisive to the protests' scale has been the international media coverage, and the popularity of the main spokesperson of the Confederación de Estudiantes de Chile (CONFECH, Chilean Students' Confederation), Camila Vallejo (Franklin 2011). A twenty-three-year-old geography student and member of the Chilean Communist Youth, Vallejo was designated a Latin American folk hero and revolutionary whose articulate speeches denounced the profiteering of the private sectors of education, the Chilean neoliberal model, and the lack of equity in university admissions.

Beginning in June 2011, and reaching a peak in August and September of the same year, schools and universities were overtaken by students, protesters went on hunger strikes, and mass street demonstrations took place - some taking on humorous formats such as kissing protests and fancy dress to attract international media and avoid heavy handed police treatment. ${ }^{18}$ Cacerolazos - the banging of pots and pans mostly used during national protests against the dictatorship between 1982 and 1987 - were also popular forms of rallying. In certain neighbourhoods of Santiago public support of student mobilizations was demonstrated by adopting the same method. Following protests in early July, President Piñera announced a US\$4 billion fund for higher education and a re-examination of its structure in an early attempt to stem the protests. However student spokespeople critiqued the government measures for failing to meet CONFECH's demands. The government made two further attempts to negotiate, but these broke down in the final months of the academic year, and Felipe Bulnes, the second minister to oversee the process, stepped down from his position. At the time of writing further protests were staged following the initiation of the 2013 Chilean academic year, and the situation is still unresolved.

Both the Penguin Revolution and the 2011 student movements are significant expressions of youth discontent over Chilean civil society and its enduring inequalities. Although government concessions were made on less consequential matters (such as a reduction in student loan rates, new terms allowing student participation in university governance), systematic inequity, social injustice, and poor educational quality were not addressed by successive Concertación governments. Whilst access to education remains biased towards higher socio-economic groups, it is also significant that Mapuche youth have demonstrated against these problems being framed in culturally homogenous terms. Below we demonstrate how Mapuche protest attempted to dislodge this homogenizing discourse around national education.

\section{Ethnic Demands}

Amidst both the Penguin Revolution and the Chilean Winter protests, Mapuche students organized themselves to support the general student demands. As Mapuche are disproportionately poor in comparison with the rest of the Chilean population, they have been particularly hard hit by the increasing privatization and price rises resulting from neoliberal reform. Yet the protests have also been an 
occasion in which to further their own demands for a transformation in the values and institutional arrangements between the nation-state, ethnic difference, and education.

During the school protests of 2006, Meli Newen, ${ }^{19}$ a Mapuche organization of secondary school pupils, was formed. The group created a network of Mapuche pupils across the Araucanía region and coordinated their actions during the protests. A conference in September 2006 saw 140 student representatives from approximately twenty-five comunas $^{20}$ across the region attend, in which obstacles to indigenous pupils' education were discussed. The organization's efforts were not insignificant amidst the protests, despite obtaining little media attention. Having obtained support from UNICEF, Meli Newen successfully arranged a meeting with the education minister, Yasna Provoste, to voice Mapuche concerns over education. The organization framed their discourse not only in terms of unfavourable education conditions, but as a problem of Mapuche-state relations in general, stating: 'for centuries the Mapuche people have suffered exclusion by the different governments who have governed the state . . giving origin to a lack of national identity in a country that does not recognise its historic and cultural roots' ${ }^{21}$

Most important were the policy changes made within the Ley General de Educación (LGE), passed in April 2008, formally incorporating IBE as one of the principal items of the Chilean education system and establishing the norms under which it is to be implemented. Although other demands, such as indigenous participation on the National Education Council, and the universal implementation of IBE for all Chileans were rejected, the LGE nonetheless represents a significant step forward in ethnic demands for promoting a more multicultural outlook within education policy (Loncón 2010).

During 2011, the Mapuche university student organization - Federation of Mapuche Students (FEMAE) - was voted into the CONFECH, and their spokespeople were elected onto the CONFECH executive board. FEMAE comprised many of the former members of Meli Newen who had become university students. The previous experiences of 2006 facilitated this successful negotiation and a higher profile within national media. However, gaining acceptance into CONFECH was not straightforward and revealed longstanding racial hierarchies and exclusionary nationalisms that delegitimized Mapuche student demands in the national student movement. On 22 May 2011, FEMAE was not voted onto the CONFECH executive board due to ingrained racism among the national student bodies and political parties represented within the confederation. According to testimony offered by the Mapuche FEMAE spokesperson Jose Ancalao, the national student organization failed to acknowledge the 'pluri-national' nature of Chilean society and the specific issues Mapuche students faced regarding state neoliberal reforms. ${ }^{22}$

However, the CONFECH soon reversed their decision when the initial vote against the involvement of Mapuche students became public via the internet and independent media. The omission of indigenous representation within the national student movement threatened to undermine their discourse of challenging the national hierarchy of elitism. In an interview several months later with the Chilean magazine The Clinic, ${ }^{23}$ CONFECH leader Camila Vallejo admitted that the initial 
vote was a mistake. Stressing principles of democracy, social justice, and civic rights, and the need for widespread reform to Chile's social structure and values, Vallejo argued that the inclusion of Mapuche representatives had led to a richer internal debate. Her statement echoed core Mapuche arguments regarding the need for equal value to be awarded to Mapuche world-views on the basis of rights and justice.

When the Mapuche world-view, their history, their values, and principles come to be incorporated into the Chilean education, I think we will be closer to a new type of society which is more just and democratic.

(Vallejo in The Clinic, September 2011)

Once accepted into CONFECH, the FEMAE focused their demands on the creation of a free state-run intercultural university, better student grants, and improvement in Mapuche boarding homes (hogares) for urban students. These demands were added onto the existing CONFECH demands directed to the Chilean government. Drawing their inspiration from the Federación de Estudiantes Indigenas (Indigenous Students Federation) active in the 1970s, a Mapuche spokesperson defined FEMAE's actions as 'derived from a historical necessity, not only to represent ourselves as a specific group, but also to retrospectively achieve rights which are being violated on a daily basis by Chilean education'. ${ }^{24}$

Beyond the specific demands of the FEMAE, this discourse challenges both the nation-state as a homogenizing force and the Chilean public's opinions regarding the legitimacy and efficacy of indigenous knowledges. When challenged on the social messaging site Twitter regarding their political preparedness, two spokespeople responded,

I am concerned above all by the winka's ignorance about us, and the superiority that accompanies that ignorance. We use feipiam, oral memory; that is our bibliography. Sometimes I say 'my grandfather says' and he heard and learnt from those older than himself. They are our library; that is where the Mapuche knowledge is. We don't need to read Lenin or Marx to fight; it is enough for us to learn from our grandparents. ${ }^{25}$

The FEMAE have therefore been an instrumental component of the recent student mobilizations, not only so as to voice a demand whose origins began at the start of the twentieth century, but also to expose a lack of intercultural openness within the movement itself. Demands for an intercultural university in Temuco have also had repercussions throughout the local academic community, where the possibilities and ramifications of such an institution have been debated. ${ }^{26}$ Negotiations between the state and indigenous peoples residing in Chile over rights of recognition, autonomy, and social/cultural expression are long-standing. Often made invisible or labelled as terrorists, the Mapuche have had an active role in challenging the nation-state's neoliberal politics and its hegemonic forms of education (Richards 2010). 


\section{Conclusions}

Chile, being one of the first Latin American countries to adopt neoliberalism, is often seen as a forerunner of economic and political stability in this region. In education, Chile also boasts several advantages over other developing countries; namely in government spending, adult and youth literacy rates, enrolment and retention, and average years of education (Delannoy 2000; UNESCO 2010). However, student-led protests in 2006 and 2011 challenged not only the inequity of Chile's education system, but also expressed growing public discontent over the failure to address the social and cultural rights of citizens. Within educational spaces the implementation of strongly neoliberal measures - most notably the Ley Orgánica Constitucional de Enseñanza (LOCE) - are therefore symptomatic of a form of national hegemony that maintains social inequalities by privileging access to higher education among the top strata of society.

Indigenous populations in Chile have been detrimentally affected by such inequity. Achievement differentials as well as ethnic discrimination are just two of the disadvantages facing Mapuche pupils in Chilean schools today (McEwan 2004). Yet long-standing indigenous demands over rights to education have challenged the state's exclusionary stance towards its citizens and its promotion of a mono-cultural and mono-linguistic national identity within educational practice. Since the 1930s, specific reforms to this system have been requested by Mapuche organizations in an attempt to create a complementary schooling system that could account for cultural and linguistic diversity. The result of these demands was the design and limited implementation of the Intercultural Bilingual Education Programme (PEIB) during the 1990s and early 2000s.

This article presents the first account of the Mapuche struggles for educational rights in relation to the recent legislative and political events in Chile. In particular, we have argued that the contribution made by Mapuche students represents a central aspect of the challenges made to the national hegemony. Chile's neoliberal multicultural model has consequently been challenged not only on socioeconomic but also ethno-national lines. IBE has contributed to this discourse by demonstrating the need to address racism and marginalization in educational spaces, and the creation of improved inter-ethnic relations founded on equality of dialogue and learning between cultures. We have questioned, however, the extent to which the neoliberal politics of Chile allows such processes to occur - often preferring a superficial recognition of difference that does not alter the national hegemony of a socially and racially stratified order.

More research remains to be done on the contested nature of Chilean national identity and the complex ways in which Mapuche youth engage with, re-work, and resist neoliberal multiculturalism and citizenship. This task is particularly urgent given that a number of secondary IBE schools have recently been established across a small number of communities in the Araucanía Region. These schools are the crucible for a series of grounded negotiations over hegemonic state nationalisms in the context of spaces that are associated with alternative visions of citizenship. Our current research is intended to critically analyse the different types of ethnic and state nationalism expressed by Mapuche youth in IBE and 
regular non-IBE educational systems, comparing youth ethnic identification, life opportunities, and political outlooks ${ }^{27}$. Although the practice of IBE remains limited and often fragmented in its implementation, it nonetheless represents an important challenge to the current politics surrounding the country's neoliberal model, and the asymmetrical relationships of its education system in particular.

\section{Acknowledgements}

The authors would like to thank Alejandro Herrera from the Instituto de Estudios Indigenas in Temuco, Chile for his input and all the participants in our current research project. We would also like to thank the reviewers for their useful comments. We gratefully acknowledge research support from the Economic and Social Research Council (ES/I031391/1).

\section{Notes}

${ }^{1}$ So called due to the colour and style of the school uniforms worn by the protesters.

2 Richards (2010), Latta (2009), Park and Richards (2007), Haughney (2007), and Bacigalupo (2004) all draw attention to the neoliberal multiculturalism prevalent in Chile today as a means of recognizing indigenous rights without implementing major changes.

3 The largest indigenous group in Chile constituting approximately $6 \%$ of the national population.

${ }^{4}$ Interview conducted in the Ministry of Education, Temuco, Chile, 11 January 2012.

5 This type of educational assimilation is found in other Latin American areas where indigenous groups were incorporated into postcolonial states via devolved educational institutions under the management of the Catholic Church (for examples, see Rival 1996; Rubenstein 2001).

${ }^{6}$ Huilliche refer to the ethnic group residing further south than the Mapuche during the colonial period.

7 The first female Mapuche to present herself as a candidate for parliament (diputada).

8 Again, there are parallels with other Latin American countries, where indigenous movements have demanded, and in some cases established, intercultural universities, catering to indigenous higher education needs (see Chapter 5 in Andolina et al. 2009; Schmelkes 2009; Téllez et al. 2006).

${ }^{9}$ Comisión verdad histórica y Nuevo Trato.

${ }^{10}$ Re-Conocer: Pacto social por la multiculturalidad.

${ }_{11}$ In 1970, 588 grants were given to Mapuche students, and by 1972 this had risen to 6,000 (Bello 1997:20).

${ }^{12}$ One of our informants in the Ministry of Education's PEIB suggested interculturalism itself is a form of postcolonialism (interview, December 2011).

13 A paper which addresses this issue has been prepared by the authors for future publication.

${ }^{14}$ Escuela Ruka Komche was 'recovered' by the Peleko Community in comuna Budi in 2008. Previously it had been under the administration of the Catholic Church organism, Magisterio de la Araucania.

15 There are eighty-one members of the CAP.

16 And likened to the social and political awakening of the Arab Spring (see Barrionuevo 2011). 
17 This coincided with the controversial decision by the Chilean government to approve a project for five hydro-electric dams to be built in Aysen in the Patagonia region of southern Chile.

${ }_{18}$ The BBC reported on most of the events throughout these months.

19 Meli Newen means 'strength from four points', referring to the importance of the balance of the four cardinal points in the Mapuche world-vision. This name was chosen so as to mirror their desire to coordinate Mapuche students throughout Chile (personal communication).

${ }^{20}$ Comunas are an administrative and political subdivision of the country's regions, and is a term that is synonymous with municipalities.

${ }^{21}$ See http://www.melinewen.es.tl/Ruka-.htm.

22 Sourced from interview conducted by Azkintuwe magazine. Available at: http:// www.azkintuwe.org/20110818_004.htm and http://www.azkintuwe.org/20110613_006 .htm.

${ }^{23}$ A political satire magazine with leftist/socialist influence. Interview available at: http:// www.theclinic.cl/2011/09/01/entrevista-camila/.

${ }^{24}$ Sourced from interview in Azkintuwe magazine. Available at: http://www.azkintuwe.org/ 20110613_006.htm.

${ }^{25}$ Sourced from interview in Azkintuwe magazine. Available at: http://www.azkintuwe.org/ 20110613_006.htm.

${ }^{26}$ The first author witnessed these debates first hand at three separate seminars: 'Interculturalidad para todos: desafíos para una educación transformadora', Universidad Católica, Sede Villarrica, 20 October 2011; 'Revitalización lingüística y políticas educativas: experiencias y propuestas respecto del mapuzugun', Universidad de la Frontera, Temuco, 21-23 November 2011; and 'Lenguas Amenazadas y Revitalización Lingüística', Universidad de la Frontera, Temuco, 4-5 June 2012.

${ }^{27}$ Papers which address these issues have been prepared by the authors for future publication.

\section{References}

Anand, Priyanka, Alejandra Mizala, and Andrea Repetto. 2009. 'Using School Scholarships to Estimate the Effect of Private Education on the Academic Achievement of Low-Income Students in Chile'. Economics of Education Review 28: 370-81.

Andolina, Robert, Nina Laurie, and Sarah A. Radcliffe. 2009. Indigenous Development in the Andes: Culture, Power and Transnationalism. Durham, NC: Duke University Press.

Bacigalupo, Ana Mariella. 2004. 'Shamans' Pragmatic Gendered Negotiations with Mapuche Resistance Movements and Chilean Political Authorities'. Identities: Global Studies in Culture and Power 11: 501-41.

Barrionuevo, Alexei. 2011. 'With Kiss-Ins and Dances, Young Chileans Push for Reform'. New York Times, 4 August. Available at: http://www.nytimes.com/2011/08/05/world/ americas $/ 05$ chile.html.

Bello, Álvaro. 1997. 'Género y etnodesarrollo: los mapuches frente a la educación superior y la formación de recursos humanos para el desarrollo'. Actas Segundo Congreso Chileno de Antropología. Vol. 1. Santiago.

Bello, Álvaro. 1999. 'Intelectuales indígenas y universidad en Chile: conocimiento, diferencia y poder'. Unpublished paper. Universidad ARCIS, Santiago de Chile.

Bengoa, José. 1985. Historia del pueblo mapuche (siglo XIX y XX). Santiago: Ediciones Sur. 
Burton, Guy. 2012. 'Hegemony and Frustration: Education Policy Making in Chile under the Concertación'. Latin American Perspectives 39: 34-52.

Cañulef, Eliseo. 1998. Introducción a la Educación Intercultural Bilingüe en Chile. Temuco, Chile: Pillan.

Carnoy, Martin. 1998. 'National Voucher Plans in Chile and Sweden: Did Privatization Reforms Make for Better Education?' Comparative Education Review 42 (3): 309-37.

Carter, Daniel. 2010. 'Chile's Other History: Allende, Pinochet, and Redemocratisation in Mapuche Perspective'. Studies in Ethnicity and Nationalism 10 (1): 59-75.

Chiodi, Francisco. 2005. 'El concepto de interculturalidad en Chile'. Rivista Di Psicolinguistica Applicata 3: 37-50.

Chovanec, Donna and Alexandra Benitez. 2008. 'The Penguin Revolution in Chile: Exploring Intergenerational Learning in Social Movements'. Journal of Contemporary Issues in Education 3 (1): 39-57.

Crow, Joanna. 2010. 'Negotiating Inclusion in the Nation: Mapuche Intellectuals and the Chilean State'. Latin American and Caribbean Ethnic Studies 5 (2): 131-52.

Delannoy, Francoise. 2000. 'Education Reforms in Chile, 1980-98: A Lesson in Pragmatism'. Country Studies Education Reform and Management Publication Series 1: 1-80.

Espinola, Viola. 1993. 'The Educational Reform of the Military Regime in Chile: The System's Response to Competition, Choice, and Market Relations'. Ph.D. dissertation in Education, University of Wales.

Foerster, Rolf and Sonia Montecino. 1988. Organizaciones, lideres y contiendas mapuches 1900-1970. Santiago: Arancibia Hnos.

Franklin, Jonathan. 2011. 'Chile's Commander Camila, the Student Who Can Shut Down a City'. The Guardian, 24 August. Available at: http://www.theguardian.com/world/2011/ aug/24/chile-student-leader-camila-vallejo?INTCMP=SRCH.

García, María Elena. 2005. Making Indigenous Citizens: Identities, Education, and Multicultural Development in Peru. Stanford, CA: Stanford University Press.

Gustafson, Bret. 2009. New Languages of the State: Indigenous Resurgence and the Politics of Knowledge in Bolivia. London: Duke University Press.

Hale, Charles R. 2002. 'Does Multiculturalism Menace? Governance, Cultural Rights and the Politics of Identity in Guatemala'. Journal of Latin American Studies 34 (3): 485-524.

Haughney, Diane. 2007. 'Neoliberal Policies, Logging Companies, and Mapuche Struggle for Autonomy in Chile'. Latin American and Caribbean Ethnic Studies 2 (2): 14160.

Howard, Rosaleen. 2009. 'Education Reform, Indigenous Politics, and Decolonisation in the Bolivia of Evo Morales'. International Journal of Educational Development 29 (6): 583-93.

Latta, Alex. 2009. 'Between Political Worlds: Indigenous Citizenship in Chile's Alto Bio Bio'. Latin American and Caribbean Ethnic Studies 4 (1): 47-71.

Loncón, Elisa. 2010. 'Derechos educativos y lingüísticos de los pueblos indígenas de Chile'. Inclusión Social y Equidad en la Educación Superior 7: 79-96.

Marimán, Pablo. 1995. Demanda por Educación en el movimiento Mapuche en Chile: 1910-1995. Temuco, Chile: Instituto de Estudios Indígenas.

Matear, Ann. 2007a. 'Tensions between State and Market in Chile: Educational Policy and Culture'. European Review of Latin American and Caribbean Studies 83: 61-82.

Matear, Ann. 2007b. 'Equity in Education in Chile: The Tensions between Policy and Practice'. International Journal of Educational Development 27 (1): 101-13.

McEwan, Patrick J. 2004. 'The Indigenous Test Score Gap in Bolivia and Chile'. Economic Development and Cultural Change 53 (1): 157-90. 
McEwan, Patrick J. 2008. 'Can Schools Reduce the Indigenous Test Score Gap? Evidence from Chile'. Journal of Development Studies 44 (10): 1506-30.

Ministry of Education. 2009. Decreto de Educación 280. Santiago de Chile: Government of Chile.

Ministry of Education. 2011. Estudio sobre la implementación de la educación intercultural bilingüe. Santiago de Chile: Government of Chile.

Mitchell, Katharyne. 2003. 'Educating the National Citizen in Neoliberal Times: From the Multicultural Self to the Strategic Cosmopolitan'. Transactions of the Institute of British Geographers 28 (4): 387-403.

Montecinos, Carmen. 2004. 'Analizando la política de educación intercultural bilingüe en Chile desde la educación multicultural'. Cuadernos Interculturales 2 (3): 35-44.

Organización de Estados Iberoamericanos. 2009. Sistematización de los distintos ámbitos de intervención en los establecimientos educacionales del programa Orígenes. Santiago de Chile: Valente.

Ortiz, Patricio. 2007. 'Intercultural Bilingual Education, Indigenous Knowledge and the Construction of Ethnic Identity: An Ethnography of a Mapuche School in Chile'. Ph.D. thesis, Graduate School of Education, University of Texas at Austin.

Park, Yun-Joo and Patricia Richards. 2007. 'Negotiating Neoliberal Multiculturalism: Mapuche Workers in the Chilean State'. Social Forces 85 (3): 1319-39.

Postero, Nancy Grey. 2007. Now We Are Citizens: Indigenous Politics in Postmulticultural Bolivia. Stanford, CA: Stanford University Press.

Richards, Patricia. 2010. 'Of Indians and Terrorists: How the State and Local Elites Construct the Mapuche in Neoliberal Multicultural Chile'. Journal of Latin American Studies 42 (1): 59-90.

Rival, Laura. 1996. 'Formal Schooling and the Production of Modern Citizens in the Ecuadorian Amazon.' In The Cultural Production of the Educated Person: Critical Ethnographies of Schooling and Local Practice, ed. Bradley A. Levinson, Douglas E. Foley, and Dorothy C. Holland. Albany: State University of New York Press.

Rubenstein, Steven. 2001. 'Colonialism, the Shuar Federation, and the Ecuadorian State'. Environment and Planning D: Society and Space 19: 263-93.

Schmelkes, Sylvia. 2009. 'Intercultural Universities in Mexico: Progress and Difficulties'. Intercultural Education 20 (1): 5-17.

Serrano, Sol. 1995. 'De escuelas indígenas sin pueblos a pueblos sin escuelas indígenas: la educación en la Araucanía en el siglo XIX'. Historia 29: 423-74.

Sieder, Rachel, ed. 2002. Multiculturalism in Latin America: Indigenous Rights, Diversity and Democracy. New York: Palgrave Macmillan.

Sznajder, Mario. 2003. 'Ethnodevelopment and Democratic Consolidation in Chile: The Mapuche Question'. In Contemporary Indigenous Movements in Latin America, ed. Erick D. Langer and Elena Muñoz. Denver, CO: Scholarly Resources.

Téllez, Sergio, Juan Carlos Sandoval, and Octaviano González. 2006. 'Intercultural University of Veracruz: A Holistic Project Promoting Intercultural Education'. Intercultural Education 17 (5): 499-505.

UNESCO. 2010. EFA Global Monitoring Report 2010: Reaching the Marginalized. Paris: UNESCO.

Wolf, Andrew. 2009. 'Articulating a Movement: A Discourse Analysis of the Pingüino Student Movement in Chile'. Masters thesis in International Studies, American University, Washington, D.C. 